\title{
High School Teaching Practice With Young People From the Periphery: A Study of the "Good Teacher"
}

\author{
Silvana Soares de Araujo Mesquita \\ Correspondence: Silvana Mesquita, PUC-Rio, Brazil. E-mail: silvanamesquita@puc-rio.br
}

Received: September 26, 2019

Accepted: January 2, $2020 \quad$ Online Published: January 3, 2020

doi:10.11114/ijce.v3i1.4546

URL: https://doi.org/10.11114/ijce.v3i1.4546

\begin{abstract}
The article discusses the teaching performance of high school teachers in a school attended by to youths of popular sectors. The objective was to identify the teaching practices of the teachers identified by students as "good teachers". The research was conducted in a public school in the periphery of the Rio de Janeiro, Brazil. The data was collected using questionnaires, observations and interviews. We identified a teaching practice marked by relational and motivational dimensions, characterizing a new professionality of the high school teacher. It turns out a "good teacher" is a relationship professional, sense builder and catalyst of the learning process of young.
\end{abstract}

Keywords: high school, good teacher, teaching, young of periphery

\section{Introduction}

The teaching complexity at any development stage is one of the greatest challenges teachers face in their work. Each teaching segment has a set of specificities that guide the teacher' practice and its conceptions about the profession itself. This text presents the results of a doctoral research study that investigated the exercise of teaching in a regular high school that serves popular sectors. The focus of this research is the specificities of high school education and teachers' pedagogical practices.

Research data were obtained from observing the daily practices within a high school, specifically of teachers teaching in the classroom. The general objective was to understand the specificities of the teachers' work at this level of education in their skills and abilities, characteristics, functions and actions as a professional responsible for educating different, heterogeneous and diverse young people in a plural and complex world.

In methodological terms, we used questionnaires to collect information from teachers and high school students, directly observed classes and interviewed managers, pedagogical staff and teachers who were described by the students as "good teachers".

Analyses and interpretations were developed based on both direct observation of the actions and speeches of the actors involved - students, teachers, managers and pedagogical team and in dialogue with the references. The theoretical basis used in the analyses was adopted from Dubet's contributions (1994, 2002, 2004); in the studies on formation and teaching profession of Formosinho (2009), Formosinho, Machado and Oliveira-Formosinho (2010), Canário (2006), Tardif (2005, 2013), Nóvoa (2009) and from Candau's works $(1983,2012)$ on the didactics (teaching practice) field.

The study had to overcome the challenge of presenting a romanticized view of the profession or an idea that the teacher must overcome all adversities apolitically and with resignation and acceptance. We set out to understand what constitutes an effective pedagogical work in a segment of education presented with many challenges which is also historically marked by the lack of identity, distancing itself from a performative vision of work, present in researches on teaching performance. Notably, the use of the term "good teacher" was evidenced as a native category, brought up by the students interviewed when they indicated in their representations that the teachers had "made the difference".

Faced with a set of data (Mesquita \& Lelis, 2015) that showed the reality of suboptimal level of results in the learning process in this education segment in comparison to the current proposals for Brazilian high school education reforms (Base Nacional Comum Curricular [BNCC], 2017 - National Common Curricular Base; Law 13,415, of February 16, 2017), this text presents evidence and alternatives that reflect on the central role of teachers in effective high school full-time education, as proposed by the Law 9,394, of December 20, 1996. 


\section{Methodology}

The state public high school's network is faced with the challenge of providing services to a heterogeneous group of young people from different social, economic and cultural contexts, as well as a multiplicity of elementary schools. High school therefore needs to be a place of opportunity for young people from lower socioeconomic classes who have earned the opportunity to attain it. Dubet (2004, p. 12) affirms that it is necessary to develop the distributive equality of opportunities, that is, to ensure high school admission is equitable by sometimes giving more to the less fortunate, to mitigate the most brutal effects of pure competition.

Thus, with the sole aim of identifying successful pedagogical practices of teachers working in this context, the research study was conducted in a regular state public high school, in the general education modality, located in the region known as 'Baixada Fluminense', Rio de Janeiro, Brazil, which is attended by young students of popular classes. It's located in a peripheral region of the city, with weaknesses in its urbanization process, due to the expansive population growth. It is characterized as a needy area by the state, with a series of infrastructural problems e.g. basic sanitation, water supply and housing conditions.

The contextual analysis illustrated that teachers worked together with young people of cultural and economic heterogeneity. In the professional field, teaching activities are developed in a network marked by political changes focused on controlling its results, but with limited investments in the valorization of the teachers' salary, formation and long working hours. In the pedagogical field, control is exerted over content taught, class hours in each group, and emphasis is placed on evaluation with limited investments in teaching resources and equipment.

The school selected, namely Einstein School (fictitious name), operates exclusively as a high school, implying that teachers in this school are professionals in this level of education. It is a large school with approximately 2,000 students in 50 classes in 2015 making it possible to compare the actions of different teachers. It is also a school that was prestigious in its region (Costa, 2008), and had been recognized by the community as a good quality school based on indicators of approval and performance.

Questionnaires were distributed to $80 \%(n=341)$ of students from the third grade, where as $82 \%(n=69)$ of teachers completed questionnaires, and participated in interviews, and classroom observations.

The teacher's questionnaires were anonymized and had close-ended questions with blank spaces for suggestions. The objective was to draw a general and comparative picture of the group of teachers interviewed on formation, career, workload and pedagogical practices. The student's anonymized questionnaire consisted of nine open-ended questions. The main objective was to obtain identify the "good teachers" and their characteristics.

A tabulation scheme was created based on the repetition of words and/or expressions used by the students to group teachers' characteristics and to construct categories to the interpret teaching practices observed in classes. This data organization facilitated the selection of "good teachers". Eleven teachers with the highest scores varying between 55.3\% and $78.2 \%$ were identified. Since we had constraints on time and human resources, four teachers with high scores and three teachers with low scores were chosen to allow for comparison during daily monitoring of classes.

We observed approximately 50 class hours of teaching done by these seven teachers with the help of a pre-defined observation record checklist that also worked as an orientation checklist. The objective was to identify the main strategies adopted by these teachers that were regarded as attractive to their classes, in the students' opinion, ranging from methodological aspects, teacher-student relationships, forms of content selection, didactic techniques used, tone of voice adopted, among others.

In this research, observation reports were developed from two models: unstructured and structured. In the unstructured model field diaries were constructed, composed of free notes, drawings, sketches recorded in the field researcher's own time and space. Within the structured model, pre-defined tokens (checklists) were adopted in which the absence or presence of a given behavior / object was recorded during the observed period. This model was also associated with open-ended questions about certain situations to be observed and described.

The aim was to articulate the two observation models, allowing for expansion and detailing (unstructured model) and support of theories and hypotheses (structured model), without excluding other analyses. Such instruments were used both the descriptions of school daily life and in making observations from the classes, specifically. The instruments for class observation were: i) Predefined form _ class observation checklist built from GERES references_Longitudinal study developed in five cities in Brazil from 2005 to 2008 (FRANCO, BROOKE, ALVES, 2008) _with adaptations for high school and also supported by theoretical references on good teachers (MESQUITA, 2017). ii) Registration in a field diary of situations other than those indicated in the checklist, including speeches by students and teachers during classes.

During the observation process, it was possible to attend different classes e.g. those introducing new content, presented by different teachers, classes that performed exercises, proofreading classes and classes with the application of an assessment tool. 
As regards the analysis strategies, observation forms had the answers to the objective questions (checklist) cataloged in a blank form, to enable comparisons between the actions of teachers. Through the number of situations observable based on pre-established criteria, we sought to identify the commonalities among teachers, the divergences and even absences. Comparative tables were elaborated reflecting the different approaches to starting, developing and ending classes, as well as the personal / strategic / motivational / relational elements that stood out in the practice of each teacher.

For further development of the analysis and the results' debate, semi-structured interviews were conducted with teachers, managers and pedagogical coordinators. The interviews high school actors to express their goals, motivations and own judgments about the students, the teaching and the knowledge.

With the data produced, the second part of this text addresses the actions and pedagogical practices adopted by the teachers that participated in the study in dialogue with the literature on work and teacher formation of the indicated references.

\section{The Exercise of Teaching in High School: the Action of "Good Teachers"}

The main questions that guided the study on classroom teaching activities were: What do these teachers do in their daily life in the classroom? How do they conduct the teaching-learning process of with high school students from the periphery? What were the singularities and approximations that characterized their teaching activity? What characteristics are most evident in classes of teachers identified as "good teachers"?

It was possible to identify two factors that highly influenced the effectiveness of the teaching: Didactics marked by the relational dimension and the motivating role of teachers in their students learning process.

\subsection{The Didactics in the Classroom Marked by the Relational Dimension}

The didactics of every teacher in the classroom is comprised of several aspects of pedagogical practice, from selection of teaching strategies to established human relationships. Aspects related to the heterogeneity of the classes, multiculturalism and commitment to social inclusion are also dimensions of fundamental didactics (Candau, 2012).However, at Einstein's school, what seemed to mostly mark this didactic dimension was the way teachers became involved with students in the sphere of class management. The recognition that teaching as a job that entailed human interactions (Tardif \& Lessard, 2005), or, as Dubet (1994) asserts, a work of one on the other. This highlighted the actions of the "good teachers" from that of other teachers. This relational dimension placed first on the work of high school teachers was identified from a series of actions observed in what teachers did.

Through data obtained from the questionnaires, teachers pointed out that disciplinary problems were the main difficulties faced in teaching high school. However, they recognized on a daily basis, disciplinary conflicts are not a grave problem and do not involve issues of violence among students. They stated that, although most of the students respected the school's rules of coexistence, they demonstrated a posture of passivity and distance from classes that interfered with the teaching practice. In fact, what seemed to be at stake in the assertion that "disciplinary problems" are a major constraint to teacher action, was teacher-student relations.

It was noticed that some of the "disciplinary problems" seemed to be related to students' lack of interest in the teaching contents, classes and the level of schooling, which resulted in a lack of attention and even refusal to carry out activities, thus generating conflicts with the teacher. Teachers recognized two striking characteristics among high school students: lack of motivation to study and lack of background knowledge to develop learning. These characteristics sometimes appeared in the teachers' discourse associated with the positions of indiscipline and rebellion. In such cases, the teacher-student relationship was associated with teachers' criticism of teacher's loss of authority and young people's lack of recognition of the "value" of school in their lives. With this reinterpretation of the comprehensiveness of the "disciplinary issues", it was possible to affirm that teachers showed the relational dimension as a singular condition for a good teaching performance. On a priority scale, teachers point out that the technical dimension of didactics, related to the availability of resources or the possibilities of practical work, had less impact on the teaching activity than the relational/disciplinary issues.

Dubet (1997), when describing one years' experience of teaching adolescents in a secondary school in France, also showed how meaninglessness the school marks was to the students' attitudes about learning. The author affirmed: "Here is a little of what I observed, and I must say that I saw exactly what the teachers said in individual or collective interviews. They do not overdo it. It is really a situation where people have great difficulties in winning over students. It's a job that starts every day, although, I repeat, it is not about bad students, aggressive, racist, but rather weak students in general" (Dubet, 1997, p. 225).

Dubet (1997) concluded that the school's situation was completely missing from the popular media, since students no longer believed that the certificates would allow them to abandon their social origin, many students had the impression that school was of no use. Of course, this problem was not limited only to the school, it had, above all, to do with the labor 
market situation. We could propose the developing of education learning that seemed more applicable to their context (p. 227).

However, among teachers identified by the students as "good teachers", the "disciplinary problems" related to lack of interest and distancing of teaching did not constitute a difficulty. These teachers established good relationships with students and built their authority and meaning of teaching with ease.

When observing classes taught by different teachers of the same discipline, the first difference observed was the form of class management and established relationships with the young students. Some teachers seemed to build a favorable learning environment by emphasizing interaction with students who were soon drawn to the teacher's appearance, language adopted and body posture. This relationship between teacher and student was established when young people felt very much part of the class. This was evidenced not only by the number of questions the teacher asked the student, but also by the number of times the student participated in giving an opinion. It was much more than that, it involved the establishment of an approximate distance between people, a directional relationship in which the student felt recognized by his/her teacher as an active subject.

During the research, based on the students' responses, it was clear that the use of media equipment, the adoption of different didactic resources, the emphasis on homework or the adoption of other innovative practices were not associated with better teachers' performance or better learning outcomes. Even though references to teacher efficacy (Brooke \& Soares, 2008) or new teacher competencies (Perrenoud, 2000; Perrenoud \&Thurler, 2002) pointed to these characteristics as being important to good teacher performance. It was the established teacher-student relational issues and, consequently, better management of class that strongly determined the making of teachers' and didactics of the "good teachers" observed.

Three sets of factors were associated with the didactic action of "good teachers" investigated: interaction, forms of treatment and construction of rules in the classroom's everyday life. In these cases, the teachers' interaction with students were marked by recognition of young people's individual characteristics, their experiences and the context in which they lived. These teachers demonstrated an awareness of who their students were and used that information to relate to them. They let the students talk about their personal lives, their likes and even their afflictions. They did not ridicule them for their choices, but they expanded their ideas through exchanges they established. The climate was conducive to learning, with the students gaining the confidence to ask and to respond actively during class. The students recognized the proximity of the teacher, discussed their doubts frequently, without fear, and often received individual attention in their portfolio.

These teachers called students by their names and won them over them by recognizing them as unique people, be it by a direct look, a touch on the shoulder or a welcoming smile. As a result, they contributed to developing the self-esteem of these young people from the periphery, who were often marginalized by their context. The forms of treatment that were established were based on respect, not by imposition of the profession, but by the conquest of the other.

"Good teachers" were able to keep the students involved for a longer time and interested in the proposed activities, even if these activities were sometimes restricted to traditional teaching practices. Therefore, discipline-control ceased to be a problem that directly impeded the teaching activity.

The result of these interactions seemed to be provided by a "relational competence" of teachers, which, to Barrère (2002), is a set of skills developed by teachers over the years, which allows them to survive and, especially, to make the educational work useful in work contexts marked by the heterogeneity of students and by loss of legitimacy of teaching authority in the classroom. It was identified that young students, from interactions with teachers, felt predisposed to learn, even if the technical-didactic resources were simple. When they perceived themselves drawn to these teachers, students intrinsically legitimized these teachers as the energizers of their learning, regardless of the discipline they taught or the variety of didactic strategies they used. As stated by Tardif \& Lessard (2005, p. 35): Teaching is a work whose object is not composed of inert matter or symbols, but of human relations with persons capable of initiative and endowed with a certain capacity to resist or to participate in the action of teachers.

Studies on primary school teachers already integrated this relational dimension teaching, highlighted the importance of face-to-face interactions and affective bonds with children (Dubet \& Martuccelli, 1996; Carvalho, 1999). This research expands this perspective to high school teaching. Both the methodological strategies and the content of the disciplines seem to occupy secondary places in the face the relational dimension in the teaching action of high school "good teachers". It can be inferred that, for the youth from the periphery, who are in constant conflict with the school's objectives and its knowledge, the valorization of good relations with the teachers presents itself as the main gateway to better results from the learning process. 
A good lesson is when the teacher is not only writing and speaking the whole class and without interacting with the students. (3rd grade high school student).

Good humor, patience, to like the class, determination, and, even being a teacher, never feels better than the students. (3rd grade high school student).

Polite and able to respect the student as he(she) is, which is cool, less strict. (3rd grade high school student).

If students like the teacher more, they learn more because of the friendship. (3rd grade high school student).

Several questions arose from these findings: Was it possible to conceive a high school education for young students, a conclusive stage of basic education, that privileged the relational dimension? Was there a risk of becoming a school of "care" with the lack of prestige of knowledge, in which the affective dimension surpassed the intellectual dimension? How could the formation of new specialist teachers in various areas incorporate the relational dimension into their curricula? Was the school relegating the transmission of knowledge and pedagogical strategies to a secondary role, to the detriment of the relational dimension of teaching?

As Moreira (1993) states, the educator-student relationship is unsustainable when students from the grassroots realize that the school is not meant for them. However, joy returns to development when the educator strives to overcome the obstacles, without neglecting the demands to be fulfilled. On the one hand, an enticing teacher, facilitates access to culture. On the other hand, the terrifying teacher, is associated with difficulties and obligations. Contradiction, however, can be experienced with joy. It is important to reiterate that the joy of the affective relationship is not the only joy of the school, whose vocation is to be a bridge between the students and the joy of culture. School is therefore the privileged place to reconcile the affective and the intellectual (MOREIRA, 1993, p. 48-49).

\subsection{The Motivating Role of the High School Teacher}

Whereas students, (as regards the relational dimension), legitimized the role of their teachers as energizers of their learning, they also highlighted other important characteristics linked to the good performance of teachers i.e. a motivational dimension. In the analysis of teaching actions, a set of factors was evident regarding the importance of the motivating role of teachers in students' learning.

The good teacher makes me learn. (3rd grade high school student).

It is the teacher who shows me the reason for learning. (3rd grade high school student).

It is only the teacher who can make me interested in the subject. (3rd grade high school student).

The motivational dimension recognizes the high school teacher as responsible for triggering a student's taste for learning. Given this analysis, were teachers be aware of the motivational responsibility in their performance in high school? At Einstein School, there was a division of opinions regarding the teacher's responsibility in student learning and the teacher's motivating role, since some teachers believed that learning depended more on the students than on teachers. This group attributed suboptimal performance of young people of the lower social classes to student's lack of interest and poor monitoring of studies by their families. This was in addition to recognizing the limited level of student knowledge as another obstacle to advancing their studies.

However, another group of teachers recognized that there was a time difference between the school and youth goals, marked by diversity of cultural logics at work, which justified disinterest and poor performance. This group managed to overcome over-blaming the students and betted that students' interest needed to be achieved by strengthening the motivational dimension of teaching.

Being a motivational teacher, meaning being able to mobilize students to learn and contribute to make sense of schooling, seemed to require a series of personal and professional characteristics, such as: high degree of commitment, professional satisfaction, high expectations regarding the teaching-learning process, reflexive practice and political-social commitment to teaching. It was identified that the motivator function was performed by a proactive posture of the teacher, striking in his actions and class management. For example in practice, "good teachers" used the mobilizing instruments like variations in language. Teachers who expressed themselves clearly and used words from the students' cultural universe received students' immediate attention. The informal language favored the students' approximation of some concepts and, consequently, knowledge. As stated by Barrère e Martucelli (2001): to teachers, good communication with students is often a reason for professional satisfaction that is increasingly distant from learning considerations. And if they are so afraid to exercise authority, it is also because, as a rule, this threatens the communication with adolescents (p. 270).

As regards language, the "good teachers" ability to use creativity and explore funny situations to give dynamism to the class made them stand out. Students liked it and were enthusiastic about the stimulus. It was observed that these teachers were able to use moments of relaxation as tools to retain students' attention. Jokes were also used as ways of criticizing inappropriate postures without the need for long speeches or "punishments". 
Another mobilizing posture developed by teachers related to their degree of commitment to the teaching process. The teachers were the ones who strived, to use multiple strategies to teach, search for new examples, and clarify new terms. They demonstrated that it was important for everyone to learn, they cared about the students who did not perform well and tried to understand the difficulty of each one from the mistakes they made. They walked around the room following the process almost on an individual basis, supervised and kept an eye on requests for help. They were teachers in a constant deliberative process in search of new strategies and ways of developing their students more. It was in the small actions of these teachers that the logic of commitment was identified for everyone's learning, such as waiting for everyone to be ready for class, creating strategies to overcome delays of the students, giving tips that favored learning, individual attention, listening carefully, adjusting the time to students' needs, worrying about the students who missed classes etc.

Studies conducted by Crahay (2013) also sought to identify the best ways for teachers to work with heterogeneity in classrooms to achieve better learning outcomes. The author concluded that students' investment in learning grew when the teacher was attentive to their progress and was ready to react as soon as one of them became distracted (p. 30)

Identifying the teaching actions associated with greater or lesser degree of performance and commitment may be associated with the posture of some teachers regarding their professional satisfaction. Tardif and Lessard (2005) point out: As we said, the students are forced clients, obliged to go to school. The centrality of discipline and order in the teaching work, as well as the almost constant need to 'motivate' students shows that teachers are confronted with the problem of the participation of their object of work - the students - in the teaching-learning work. They need to convince students that 'school is good for them' (p. 35).

\section{Conclusion}

These two dimensions of teaching work, relational and motivational, observed in the practice of high school teachers and associated with the achievement of students' involvement in learning, stand out as individual initiatives of teachers. Most of the strategies that each investigated "good teacher" developed were part of the combination of their individual experiences, professional or otherwise, and we remarked by the personality of each teacher. The absence of collaborative work observed among high school teachers, the disciplinary and fragmented organizational model adopted, and the lack of effective school-centered formation spaces characterized the actions of these teachers as a solitary work.

During the research, each teacher presented him/herself in isolation from his/her classroom, marked by individual daily planning, a series of improvisations and the emphasis on his/her personal characteristics. As Dubet (1994) would say, the teacher expresses in his/her job, his/her personality and leaves impressions, the class becomes the reflection of the personality of this teacher and his/her work. However, it is possible to identify similarities in the actions of "good teachers" identified by students with the findings of large-scale school effectiveness surveys (Brooke \& Soares, 2008). It is possible to recognize, on the one hand, that:

- effective teachers teach in small steps, they are not evaluative, and keep learning relaxed (p. 365);

- they relate well to students, resulting in fewer behavior problems (p. 365);

- they establish an environment of respect and discipline in the classroom, they contribute to student performance (p. 496);

- effective teachers monitor students' progress (p. 322);

- they maximize the time spent on student interaction (p. 316). (Brooke \& Soares, 2008).

On the other hand, one cannot bet on a simple list of actions or "ready-made recipes", associating them with good results as a cause-and-effect process. Sammons et al. (1994 as cited in Brooke \& Soares, 2008) drew attention to the constant need for additional case studies to better understand school effectiveness and, the performance of teachers considered effective. There are no simple answers to complex questions, the authors say.

When thinking about the centrality of the role of the teacher in working with young students from the periphery, it was possible to verify the relational and motivational dimension as guiding elements of the teaching activity. From both students and teachers' point of view, the need to practice teaching through the construction of meaning for the learning of content became a singular condition for the process of teaching and learning to be established.

The young public school' students, when listing the characteristics of their "good teachers", highlighted something that needs attention: the lack of meaning of the knowledge transmitted by middle school. To this end, these students assigned to teachers the role of "meaning builder" (Canário, 2006, p. 22). According to Canário (2006), understanding the teacher as a meaning constructor is a new dimension of the teaching work that stands out due to the need to establish a link between the school institution and the diversity of expectations and action logic presented by a heterogeneous group of students. Or, as Dubet (2002) affirms, in the face of the decline of the institutional school program, teaching work becomes legitimized by relationships, which are characterized by work on the other, in search of authenticity and 
recognition of their practice by this another, in the case of young people of high school.

With this, it can be said that a teacher needs to present him/herself as a catalyst, as Formosinho (2009) points out. Metaphorically, a catalyst in the language of Chemistry is an element that accelerates a chemical reaction, making the generation of products viable. Thus, the catalyst teacher would be the one capable of enabling the teaching process to be effective, generating positive results, through motivation and mobilization of the student to learn. And how does the teacher become a catalyst and constructor of meanings?

This research points out that it stems from the relational dimension. Repeatedly, in the action of teachers and in the voice of students, the relational dimension is developed and is associated with the motivating role of teachers. It is evident that the teacher as a professional in the relationship needs to approach the young persons and have them as allies and not as problems. It has been identified that the construction of a valued image of the youth of the periphery constitutes an important condition for the development of a positive pedagogical relation. As Canário (2006, p. 22-23) affirms: The meaning deficit of school situations is, moreover, something common to teachers and students, who are, together, prisoners of the same problems and constraints. This means that building another professionality for teachers is not prior, but rather concomitant with building another relationship with students.

It is possible to conclude that a high school attended by the popular classes needs to construct this new professionality in teachers' work, suggesting the re-creation of the teacher's job (Canário, 2006) or a new reconfiguration (Dubet, 2002). Beyond the content taught, the emphasis on knowledge or the intellectual profile of teachers, the centrality of the role of teachers is evident in the motivational and relational dimensions.

Tardif and Lessard (2005), affirmed that a new way of understanding teaching is to assume it as an interactive work, recognize that this logic of action is often less valued, both in formation and in the teaching profession. To the authors, "the logic that prevails in the act of teaching is that of a work with human beings, on human beings, for human beings" (Tardif \& Lessard, 2005, p. 31). Thus, work on human beings considers, above all, relationships between people, involving negotiation, persuasion, control, seduction, and promises.

To Nóvoa (2009), teachers live in an atmosphere loaded with affections, feelings and conflicts. Betting on detachment from these emotions is like denying one's own work. There is no neutrality in pedagogical practice; other authors (Candau, 2012; Cunha, 1996; Tardif \& Lessard, 2005; Dubet, 2002) also point out what was also proved to be a challenge at Einstein School and a necessity for the work of teachers to attain involvement and understanding of the other .

All these ideas and factors related to the complexity of teaching identified during high school teaching work indicate the need for more appreciation of a set of relational and reflective professional skills. According to Nóvoa (2009), it is necessary to overcome the idea that it is enough for teachers to master their teaching subject and have a certain aptitude for communication, since this only leads to the discredit of the profession by reducing the status of teaching to something simple and natural. It is necessary to identify the specific and duly recognized knowledge of good teaching performance.

It was concluded that new alternatives of teaching quality may be hidden within the school itself and in solitary a group of "good teachers" recognized only by their own students. The investment in collective work, reflexive practice, co-participation and involvement, associated with the strategies of monitoring the teaching work, are configured as paths for professional development of teachers and improvements in the teaching-learning process. The broadening of conceptions of what constitutes a high school "good teacher" can contribute both to the institution of policies to foster the development of the teaching career and to the courses of initial and continuous formation of specialist teachers.

\section{References}

Barrère, A. (2002). Les enseignants au travail. Routines incertaines. Paris, France: Edition L'Harmattan.

Barrère, A., \& Martucelli, D. (2001). A escola entre a agonia moral e a renovação ética. Educação \& Sociedade, 22(76), 258-277. https://doi.org/10.1590/S0101-73302001000300014

Base Nacional Comum Curricular. (2017). Brasília, Brazil: MEC, Retrieved on July 23, 2019 from http://basenacionalcomum.mec.gov.br/

Brooke, N., \& Soares, J. F. (2008). Pesquisa em eficácia escolar: origem e trajetórias. Belo Horizonte, Brazil: UFMG.

Canário, R. (2006). A escola tem futuro: das promessas as incertezas. Porto Alegre, Brazil: Artmed.

Candau, V. M. (1983). A Didática em Questão. Petrópolis, Brazil: Vozes.

Candau, V. M. (2012). Rumo a uma Nova Didática. Petrópolis, Brazil: Vozes.

Carvalho, M. P. (1999) Ensino, uma atividade relacional. Revista Brasileira de Educação, (11), 17-31. Retrieved from http://www.anped.org.br/sites/default/files/rbe/files/rbe_11.pdf

Costa, M. da. (2008). Prestígio e hierarquia escolar: estudo de caso sobre diferenças entre escolas em uma rede 
municipal. Revista Brasileira de Educação, 13(39), 455-469. https://doi.org/10.1590/S1413-24782008000300004

Crahay, M. (2013). Como a escola pode ser mais justa e mais eficaz? Cadernos Cenpec, 3(1), 9-40. https://doi.org/10.18676/cadernoscenpec.v3i1.202

Cunha, M. I. da. (1996). O bom professor e sua prática. São Paulo, Brazil: Papirus.

Dubet, F. (1994). A Sociologia da Experiência. Lisboa, Portugal: Instituto Piaget.

Dubet, F. (1997). Quando o sociólogo quer saber o que é ser professor. Entrevista com François Dubet. Revista Brasileira de Educação, 65, 222-231. Retrieved from http://anped.tempsite.ws/novo_portal/rbe/rbedigital/RBDE05_6/RBDE05_6_19_ANGELINA_E_MARILIA.pdf

Dubet, F. (2002). El declive de la institución: profesiones, sujetos e individuos en la modernidad. Barcelona, España: Gedisa.

Dubet, F. (2004). O que é uma escola justa? A escola das oportunidades. São Paulo, Brazil: Cortez. https://doi.org/10.1590/S0100-15742004000300002

Dubet, F., \& Martuccelli, D. (1996). A l'école: sociologie de l'experience scolaire. Paris: Seuil.

Formosinho, J. (2009). Formação de professores. Aprendizagem profissional e aç̧ão docente. Porto, Portugal: Porto, 2009.

Formosinho, J., Machado, J., \& Oliveira-Formosinho, J. (2010). Formação, desempenho e avaliação de professores. Mangualde, Portugal: Pedago.

Franco, C., Brooke, N., \& Alves, F. (2008). Estudo longitudinal sobre qualidade e equidade no ensino fundamental brasileiro: GERES 2005. Ensaio: aval.pol.públ. Educ., 16(61), 625-637. https://doi.org/10.1590/S0104-40362008000400008

Law No 13,415 (2017, February 20). Retrieved from http://www.planalto.gov.br/ccivil_03/_ato2015-2018/2017/lei/L13415.htm

Law no. 9,394 (1996, December 20). Retrieved from http://www.planalto.gov.br/ccivil_03/LEIS/L9394.htm

Mesquita, S. S. A., \& Lelis, I. A. O. M. (2015). Cenários do Ensino Médio no Brasil. Ensaio: Avaliação e Políticas Públicas em Educação, 23(89), 821-842. https://doi.org/10.1590/S0104-40362015000400002

Moreira, A. F. B. (1993). Conhecimento, Currículo e Ensino: questões e perspectivas. Em. Aberto., 12(58), 45-53. http://dx.doi.org/10.24109/2176-6673.emaberto.12i58.1890

Nóvoa, A. (2009). Professores imagens do futuro presente. Lisboa, Portugal: Educa.

Perrenoud, P. (2000). Dez novas competências para ensinar. Porto Alegre, Brazil: Artmed.

Perrenoud, P., \& Thurler, M. G. (2002). As competências para ensinar no século XXI: A formação dos professores e o desafio da avaliação. Porto Alegre, Brazil: Artmed.

Tardif, M. (2005). Saberes docente e formação profissional. Petrópolis, Brazi: Vozes.

Tardif, M. (2013). A profissionalização do ensino passados trinta anos: dois passos para a frente, três para trás. Educação \& Sociedade, 34(123), 551-571. https://doi.org/10.1590/S0101-73302013000200013

Tardif, M., \& Lessard, C. (2005). Trabalho docente: elementos para uma teoria da docência como profissão de interações humanas. Petrópolis, Brazil: Vozes.

\section{Copyrights}

Copyright for this article is retained by the author(s), with first publication rights granted to the journal.

This is an open-access article distributed under the terms and conditions of the Creative Commons Attribution license which permits unrestricted use, distribution, and reproduction in any medium, provided the original work is properly cited. 